\title{
Initial Stages of Ontogenesis of Capparis spinosa L. in the Conditions of the Tashkent Botanical Garden (Uzbekistan)
}

\author{
Gulizebo B. Vaisova1, Tashkhanim Rakhimova ${ }^{2}$, Anorjon Matkarimova1 \\ ${ }^{1}$ M. Ulugbek National University of Uzbekistan, Tashkent, Uzbekistan \\ ${ }^{2}$ Institute of Botany of the Academy of Sciences of the Republic of Uzbekistan, Tashkent, Uzbekistan \\ Email: tashkhanim@mail.ru
}

How to cite this paper: Vaisova, G.B., Rakhimova, T. and Matkarimova, A. (2021) Initial Stages of Ontogenesis of Capparis spinosa L. in the Conditions of the Tashkent Botanical Garden (Uzbekistan). American Journal of Plant Sciences, 12, 1613-1623. https://doi.org/10.4236/ajps.2021.1211112

Received: September 28, 2021

Accepted: November 2, 2021

Published: November 5, 2021

Copyright $\odot 2021$ by author(s) and Scientific Research Publishing Inc. This work is licensed under the Creative Commons Attribution International License (CC BY 4.0).

http://creativecommons.org/licenses/by/4.0/

\begin{abstract}
The initial stages of the ontogenesis of Capparis spinosa L. (Capparidaceae) were studied for the first time in the conditions of the Tashkent Botanical Garden of the Republic of Uzbekistan. In plants, the seed peel is very dense and hard. Therefore, in laboratory and field conditions, the germination of seeds is low. In natural conditions, the seeds of mature fruits do not germinate for a long time (4 - 5 years). The seeds after undergoing cold stratification gave positive results $(70 \%-80 \%)$. Also, information is given about the nature of the use of its useful properties in the national economy as both forage, medicinal, and honey-bearing use. Plants are quite resistant to xerothermic factors, parasites and diseases. Capparis spinosa is a very promising plant adapted to various environmental conditions and can be used for degraded pastures of desert and foothill regions of the Republic of Uzbekistan.
\end{abstract}

\section{Keywords}

Capparis spinosa, Ontogenesis, Seeds, Root, Flower, Fruit, Tashkent, Uzbekistan

\section{Introduction}

Currently, the mobilization of botanical resources for the expedient development of territories that are not suitable for the cultivation of cultivated plants is of great importance. The development of these lands is a huge reserve for increasing the production of feed and food products. In the Republic of Uzbekistan, the efficiency of using semi-deserts as pastures is very low, since their yield is variable in different years and on average does not exceed $3-3.5 \mathrm{~kg} / \mathrm{ha}$. Also, 
the seasonal use of pastures is very short, covering mainly the spring and partly the summer months. In the autumn and winter seasons, such lands are considered practically unusable. In this regard, a significant increase in the efficiency of pasture use is currently an urgent task. To solve this significant problem, one of the promising ways is the development of caper plantations.

In recent years, the demand for caper buds and flowers has been increasing in foreign countries, especially in the Mediterranean countries. Collecting flowers and buds from natural caper populations is becoming popular. And this leads to negative consequences: to the complete disappearance of this species from nature. Since this plant is considered a highly profitable source, it also grows on non-irrigated lands and gives high yields during a long vegetation period (up to 15 years), therefore it is necessary to introduce culture and create production plantations.

In this regard, the study of biological and economically valuable characteristics of plants from thermoxerophytic species is relevant. And one of the very promising wild plants is the prickly caper-Capparis spinosa $\mathrm{L}$. that is relevant.

There are 37 genera and about 400 species in the Capparidaceae family on the globe [1]. In the flora of Central Asia in this Capparidaceae there are two genera: the genus Capparis L. that occurs with two species: C. rosanowiana B. Fedtsch., C. spinosa L.; genus Cleome L. with eleven species: Cleome ariana Hedge et Lamond, C. coluteoides Boriss., C. fimbriata Vicary, C. gordjaginii Popov, C. khorassanica Bunge et Bienert, C. lipsky Popov, C. quinquenervia DC., C. raddeana Trautv, $C$. rostrata Bobrov, $C$. spinosa Jacq., $C$. tomentella Popov [2]. In Uzbekistan, there are both species of the genus Capparis L., and from the genus Cleome L. 4 species: C. fimbriata Vicary, C. gordjaginii Popov, C. lipsky Popov, C. tomentella Popov [3].

Capparis spinosa is most widely distributed in Central Asia and beyond, compared to other species. Within Central Asia, capers are common in all regions (except the mountains and highlands) of Uzbekistan, Kazakhstan, Kyrgyzstan, Tajikistan and Turkmenistan. In the conditions of Central Asia and the Caucasus, capers are confined mainly to the plains and foothills, and rarely inhabit the lower band of the mountain belt. Our observations (2017-2021), conducted in some places of the Republic of Uzbekistan, showed that the maximum height of the distribution of caper thickets does not exceed $1200-1300 \mathrm{~m}$ above sea level.

The range of the Capparis is very wide and covers many areas of the globe-from the mesothermic regions of Europe to the extreme atmospheric conditions of the deserts of Mongolia on the one hand and Libya on the other [4].

In Central Asia, capers live on the loess soil of foothill plains and hills with more or less deep groundwater in the cracks of rocks on mountain slopes and often on the gravel-stony soil of low mountains. He usually chooses a denser substrate and southern exposures of the slopes of hills and mountains.

In cities and villages, capers can be found in old cemeteries, basements and near human habitation, in the cracks of the walls of stony buildings. The plant, 
both weedy and ruderal, is found along the edges of roads, along railways. Its distribution is confined to loamy gray soils that were under culture, to the banks of ditches, desert foothills with clay and gravelly soils. Sometimes it forms entire thickets over large areas, is eaten by sheep, camels and horses [3]. In the karakul farms of Central Asia and Kazakhstan, where rains are extremely rare in summer, there is a shortage of feed in the conditions of desert and foothill pastures. Capers, like phreatophytes, thanks to a powerful, deep-reaching root system (up to a depth of $10-18 \mathrm{~m}$ and deeper), continuously vegetate from spring until the onset of autumn frosts [4].

The economic advantages of capers are known to the peoples of Asia and Europe. The population of Central Asia has long used their seeds to obtain edible oil, eats both parts and the pulp of the fruit (contains 12\% sugar and more than $12 \%$ protein substances). In addition, capers are used in folk medicine: medicinal remedies are prepared from its aboveground and underground organs against hemorrhoids, diarrhea, throat diseases, as well as for headache and toothache with rheumatism, tuberculosis, various tumors and ulcers. Caper leaves contain about $1 \%$ rutin [4] [5]. The fruits of prickly capers contain vitamin C (up to 136 $\mathrm{mg} \%$ ), a significant amount of iodine (up to $27 \mathrm{mg} \%$ ); the seeds contain up to $35 \%$ of reddish semi-drying fatty oil (Figure 1); and the root bark contains the glycoside capparidin. The bark of the roots of prickly capers contains $1.2 \%$ of alkaloids. Traditional medicine uses a decoction of caper roots for liver diseases, nerve weakness, rheumatism, jaundice. The fruits of capers strengthen the liver, heart, lungs and spleen, and also help with goiter, diabetes, angina. The juice from the leaves has an anthelmintic effect [6].

In beekeeping, capers are used as a first-class honey plant. Its flowers secrete nectar in very large quantities. Especially valuable, from the point of view of beekeeping, is the duration of the flowering period-from the beginning of May to November. The flowers open at $17-18$ hours and close the next day at $12-13$
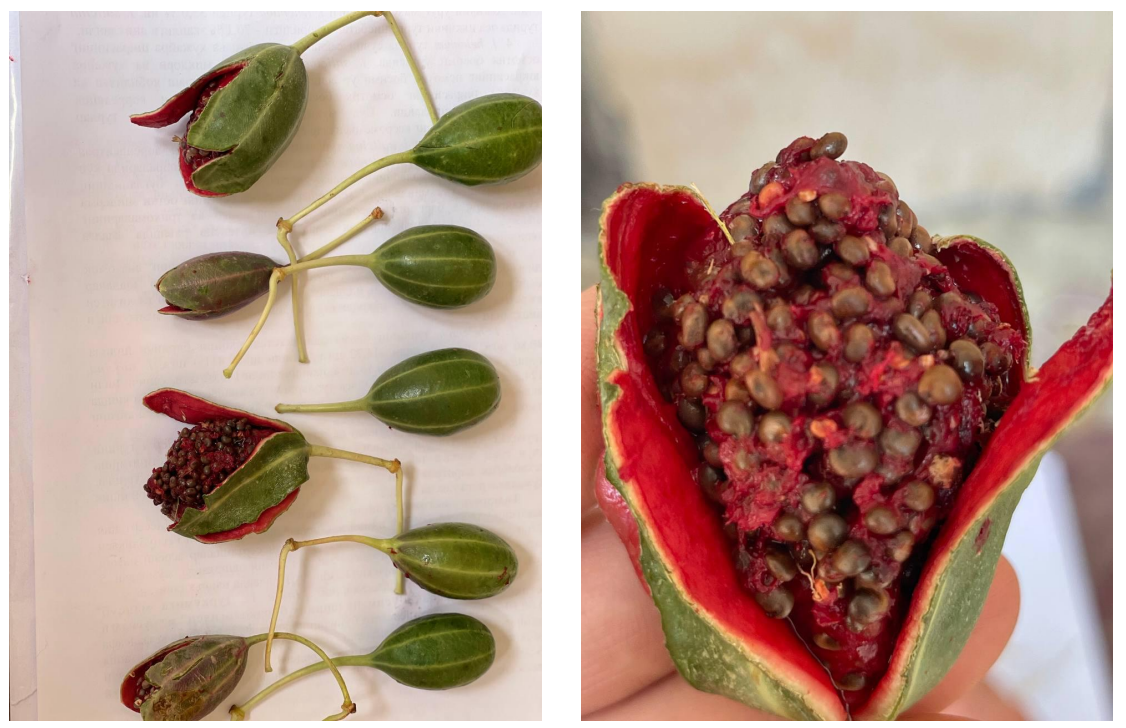

Figure 1. Fruits of Capparis spinosa. 
hours. The allocation of honey is noted at the same time. On average, one flower contains $36 \mathrm{mg}$ of honey and $37 \%$ of sugars. In beekeeping, it is considered the highest honey-bearing plant [7].

Since ancient times, marinades have been prepared from caper buds in many countries of the world, for example, in the Crimea, the Caucasus and Transcaucasia. Paints are obtained from the roots. The aboveground parts of capers are used for food [4] [8].

In the literature there is information about the cultivation of Capparis in Crimea. In the conditions of Uzbekistan and Central Asia, the issues of the use and cultivation of capers were studied very poorly. The only exception is the work of K. Z. Zakirov and R. Khudaiberganov [4]. There are data on the chemical composition of the fruits of Capparis spinosa and on cultivation in artificial conditions of the Jizzakh region [9]. Almost all the data relate mainly to the use of buds, fruits and other parts of the plant in the canning industry.

Publications on the pharmacological properties of $C$. spinosa can be seen in highly rated international journals [10]-[19].

The research area-the Tashkent Botanical Garden is located at an altitude of $480 \mathrm{~m}$ above sea level. The soil is a typical serozem. The climate of the city of Tashkent is continental. Summer is hot, and winter is relatively cold. The average monthly air temperature in July is $+27^{\circ} \mathrm{C}$, the absolute maximum for July is $+44.6^{\circ} \mathrm{C}$, the absolute minimum temperature is $-29.5^{\circ} \mathrm{C}$ in January [20].

The purpose of this research is to study the initial stage of the ontogenesis of Capparis spinosa in the conditions of culture of the Tashkent Botanical Garden and natural habitats for introduction into culture by seed.

\section{Material and Methods}

The object of research is Capparis spinosa-a perennial herbaceous plant from the family Capparidaceae. A plant with creeping branched stems, up to $2.5 \mathrm{~m}$ long, glabrous or diffusely pubescent white hairs. The leaves are rounded; obovate or elliptical, 5 - $6 \mathrm{~cm}$ long, with a small prickly tip at the top, green, glabrous short-stemmed. The flowers are large, $5-8 \mathrm{~cm}$ wide, white, pinkish when blooming. The fruits are obovate or round-oblong, multi-seeded, berry-shaped $2.5-4.5 \mathrm{~cm}$ long, $1.5-3 \mathrm{~cm}$ wide. Seeds are $3-3.5 \mathrm{~mm}$ long, kidney-shaped, brown, dotted, with a spout. Blooms in May-June, bears fruit in July-August (Figure 2).

For the germination of seeds in laboratory and field conditions, the methodology of T. A. Rabotnov [21], "Methodological guidelines for seed science" [22], "Handbook on the germination of resting seeds" by M.G. Nikolaeva et al. [23] was used, the method of A. Rabbimov et al. was used for the cold stratification of seeds [24]. The initial stages of plant ontogenesis were studied by the method of T.A. Rabotnov [25] and I.G. Serebryakov [26]. The method of I.V. Borisov [27] and I.N. Beideman [28] was used for the seasonal development of plants. 


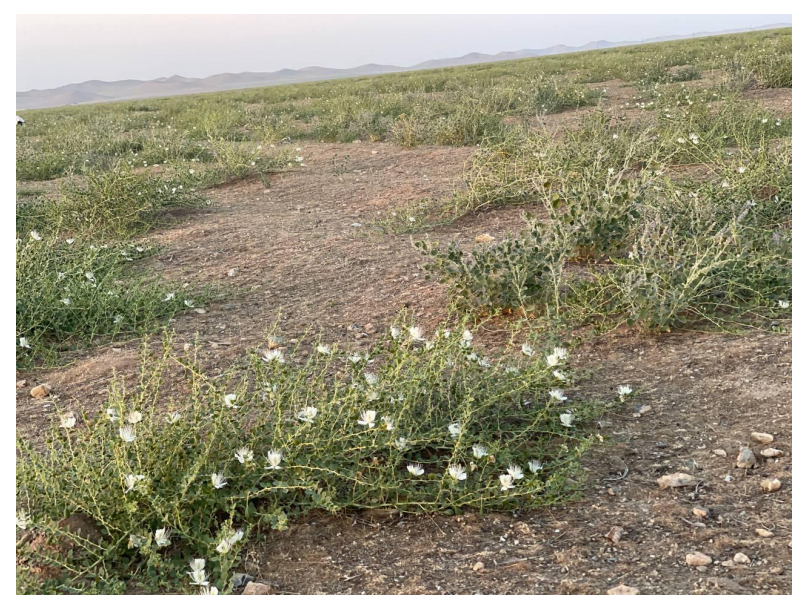

Figure 2. General view of Capparis spinosa in natural growing conditions.

\section{Results and Discussion}

The latent period. The weight of 1000 seeds is $10.5 \mathrm{~g}$. The plant propagates by seed and vegetative means (Figure 3 ). The seed peel is very dense and hard. Due to this in laboratory and field conditions, the germination of seeds is very low. Under natural conditions, even the seeds of mature fruits do not germinate for a long time ( $4-5$ years). The use of known stimulation methods (the action of sulfuric and formic acids of different concentrations, mechanical treatment with sandpaper, sand, boiling water and cold water) gave insignificant results. The seeds were stored underground from December to March to undergo cold stratification. Since March, they have been sown under film in the field. Not resistant to cold weather. At a soil temperature of $16^{\circ} \mathrm{C}-18^{\circ} \mathrm{C}$, at an air temperature of $+20^{\circ} \mathrm{C}-25^{\circ} \mathrm{C}$, the plant grows and develops well.

The virginal period. Sprouts. At the end of March, the germination rate was $70 \%-80 \%$. In mid-April, mass shoots were observed. During this period, the average air temperature was $+13^{\circ} \mathrm{C}-+16^{\circ} \mathrm{C}$. The seedlings in this state had 2 lanceolate leaves $0.3-0.5 \mathrm{~cm}$ long, $0.2-0.3 \mathrm{~cm}$ wide, the length of the hypocotyl is $0.8-1.2 \mathrm{~cm}$, the root deepened by $1-2 \mathrm{~cm}$. This stage lasts only $15-20$ days (Figure 3).

The juvenile stage. At the beginning of May, the height of the seedlings was 2 $-2.5 \mathrm{~cm}$, round first and second leaves are formed, real leaves. The leaf size is 0.5 $-0.7 \times 0.4-0.5 \mathrm{~cm}$, two cotyledon leaves are preserved. The root deepens by 2.5 $-3 \mathrm{~cm}$. On May 18, some plants had the third and fourth leaves. At this time, the average air temperature was $29^{\circ} \mathrm{C}$. The height of the plants reached $2.5-3 \mathrm{~cm}$. In early June, at an air temperature of $37^{\circ} \mathrm{C}-38^{\circ} \mathrm{C}$, the height reached $4-4.5 \mathrm{~cm}$ with 5 - 6 real leaves, the length of which was $1.5-1.8 \mathrm{~cm}$, and the width was 1.3 $-1.5 \mathrm{~cm}$. The roots reach a length of $4-6 \mathrm{~cm}$ with thin secondary lateral roots (Figure 4). In mid-June (14.06), the appearance of thorns was noted in juvenile plants, that the stipules gradually acquire the appearance of thorns, their ends are curved, have up to $2 \mathrm{~mm}$ in length. At the beginning of July (5.07), the height of the plants reached $5-6 \mathrm{~cm}$, the size of the leaves increased by $2-2.5$ 


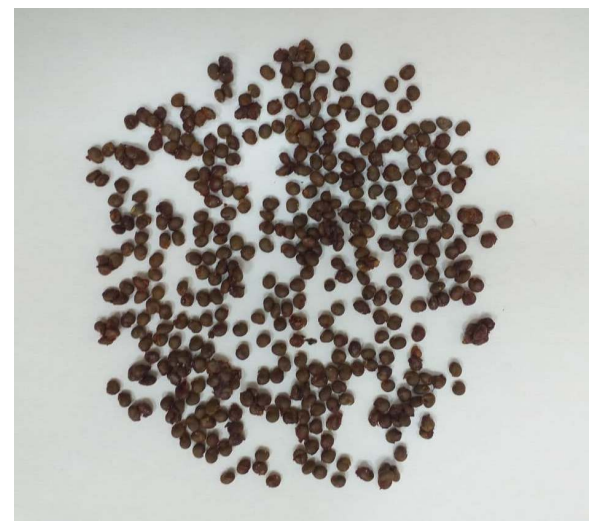

(a)

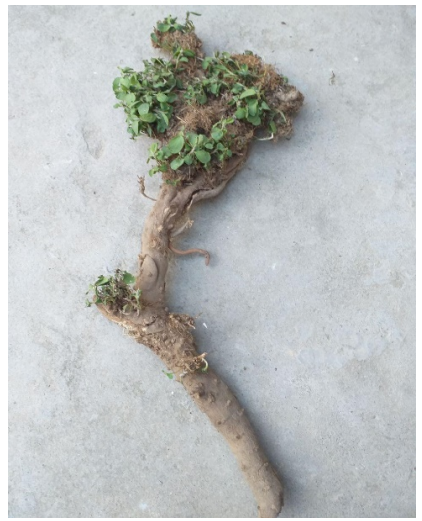

(b)

Figure 3. Seeds (a) and root (b) of Capparis spinosa.

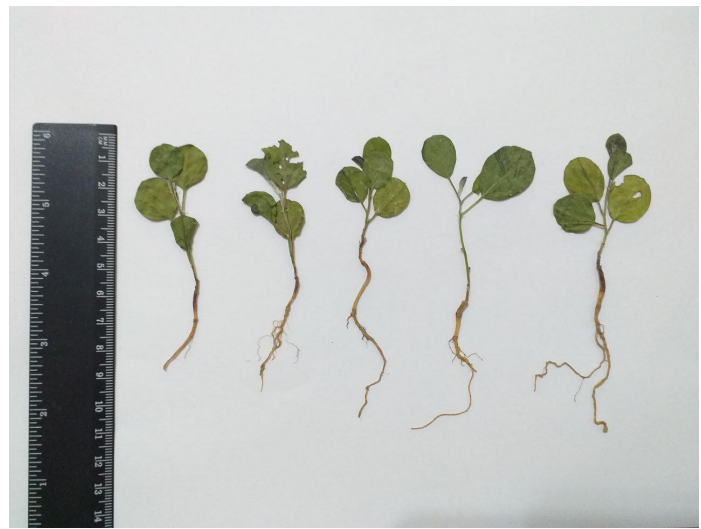

(a)

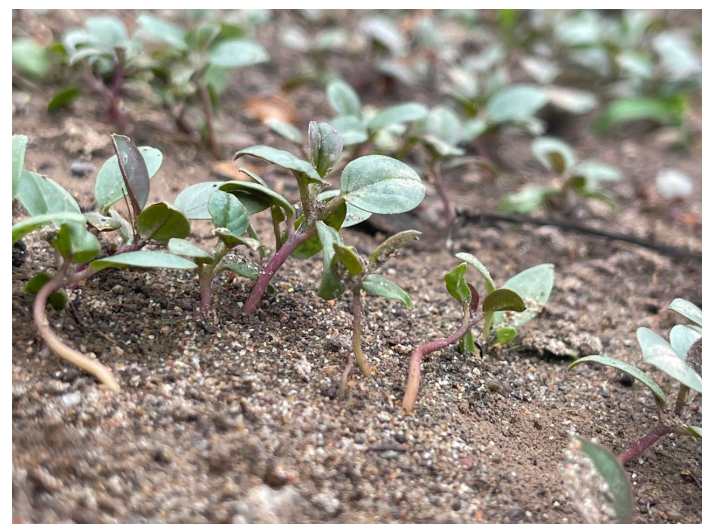

(b)

Figure 4. Juvenile plants (a), in the field (b).

$\mathrm{cm}$ long, $1.5-2 \mathrm{~cm}$ wide. In the soil horizon of $2-3 \mathrm{~cm}$, you can see branched lateral roots of the third order, $1-3 \mathrm{~cm}$ long. The juvenile stage lasts exactly 4 months (from May to the end of August).

At the end of August (31.08) at a temperature of $34^{\circ} \mathrm{C}-36^{\circ} \mathrm{C}$, the length of the stem in crops reached up to $20-25 \mathrm{~cm}$. This is an immature age-related condition, and they developed quite intensively. At this time, the caper bush consists 
of only one main stem and with several branches of the second order. Around the root neck and in the lower part of the stem at the root neck, 5 - 6 wintering renewal buds are laid, and next year stems grow from these buds. The diameter of the root neck is $0.3-0.4 \mathrm{~cm}$. The length of the taproot is $15-20 \mathrm{~cm}$ and several lateral roots are $7-10 \mathrm{~cm}$ long. At the end of September (20.09), at an air temperature of $35^{\circ} \mathrm{C}-37^{\circ} \mathrm{C}$, the stem length in the crops reached $30-35 \mathrm{~cm}$ in the crops. The leaves have an oval, sometimes rounded shape with a tip at the top. In the first year of the growing season, capers developed intensively in the summer. Thus, the virginal period of the first year lasts up to $160-165$ days until the end of September and the plants remained in the adult virginal state (Figure $5)$.

Young generative plants. The results of our research (2017-2021) on the cultivation of plants from seeds showed that in the conditions of culture, some caper individuals (about 30\%) begin to bloom in the second year of life. At the end of April, buds were noted, in mid-May, at a temperature of $36^{\circ} \mathrm{C}-37^{\circ} \mathrm{C}$, the plant bloomed. Mass flowering lasted 3.5 - 4 months. At the beginning of July, fruit ripening was noted and lasted until the end of September. On one plant, the simultaneous appearance of a bud, flower and seed was observed. It takes 15 - 20 days from the formation of buds to flowering, and 45 - 50 days from flowering to fruit ripening. The flowers mostly opened in $1700-1800$ hours. The opening of one flower lasts 2.5 - 3 hours. The flowering process depends on climatic conditions, with an increase in air temperature and a decrease in relative humidity, the number of opened flowers increases. The caper's need for high temperature, both during seed germination and during growth and development, once again confirms its thermophilic nature. In June and July, there is a very rapid growth in capers. At the end of July, the height of the stems reaches $60-70 \mathrm{~cm}$, the root penetration depth is more than one meter, numerous lateral roots of the second and third order were formed. At the end of August and September, the increase is noticeably reduced. During the growing season, the length of the stems of individual biennial plants reached $70-80 \mathrm{~cm}$ (Figure 6).

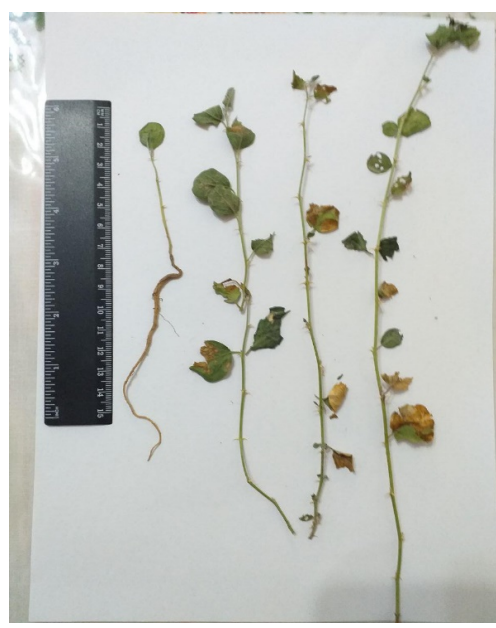

Figure 5. Virginal plants. 


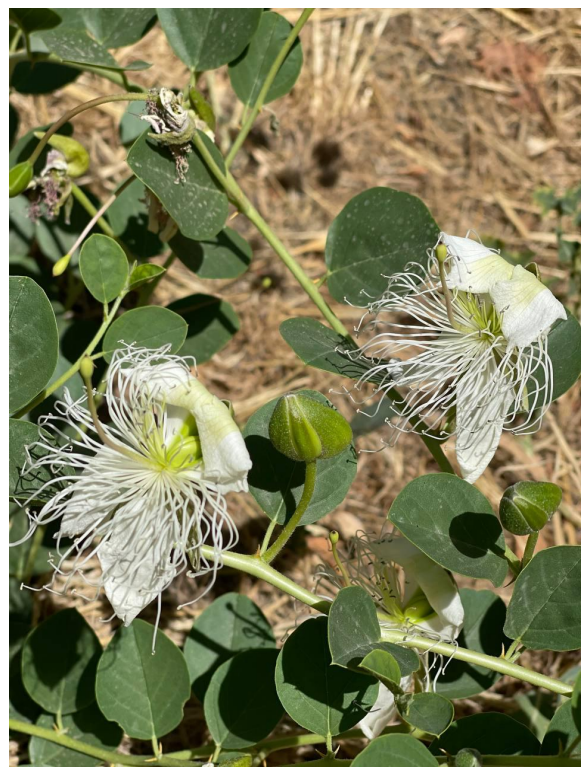

Figure 6. Generative plants.

We studied middle-aged generative individuals in the natural conditions of the city of Tashkent. In the month of December 2020, up to 50 pieces of buds were laid in one bush. At the beginning of April 2021, at a temperature of $11^{\circ} \mathrm{C}$ $12^{\circ} \mathrm{C}$, the buds were observed to open, which sprouted up to $0.3-0.5 \mathrm{~cm}$. In mid-April, the buds sprouted by $2-3 \mathrm{~cm}$, and on April 20, at a temperature of $15^{\circ} \mathrm{C}-16^{\circ} \mathrm{C}$, annual shoots reached $15-20 \mathrm{~cm}$. In one annual shoot, leaves were formed in an amount of $10-12$ pcs. the size of $1 \times 1 \mathrm{~cm}$. At the end of this month, with intensive growth at a temperature of $25^{\circ} \mathrm{C}-26^{\circ} \mathrm{C}, 18$ annual shoots were formed, the length of which reached $50-60 \mathrm{~cm}$. In early May, at a temperature of $34^{\circ} \mathrm{C}-35^{\circ} \mathrm{C}$, annual shoots reached an average of up to $100 \mathrm{~cm}$. This month, the formation of buds was observed.

In 10.05.2021, mass budding and the beginning of flowering were noted. The length of annual shoots reached up to $130 \mathrm{~cm}$. In the middle of May, the height of annual shoots reached $150 \mathrm{~cm}$, at the end of the month-at a temperature of $28^{\circ} \mathrm{C}-30^{\circ} \mathrm{C}$, an average of $180 \mathrm{~cm}$. In mid-June, the height of annual shoots reached up to $240 \mathrm{~cm}$. The length of the shoots of the second order is up to 80 $100 \mathrm{~cm}$. In the phase of mass flowering, the plant forms from 35 to 40 flowers on one bush. At the same time, the fruiting phase began. This month, the simultaneous formation of buds, flowers and fruits was observed on one plant. The flowering process depends on the climatic conditions. With an increase in air temperature and a decrease in relative humidity, the number of opened flowers increases. The caper's need for high temperature, both during seed germination and during growth and development, once again confirms its thermophilic nature. In the summer months, there is a very intensive growth and development of capers. In mid-July, the length of annual shoots reached up to $4 \mathrm{~m}$. The length of the leaves is $4 \times 4.5 \times 5 \mathrm{~cm}$, the length of the fruit is $4 \mathrm{~cm}$, the width is $2-3$ $\mathrm{cm}$. the drying of the leaves was not noted. In August-September, the growth 
and development of the plant continues, in October at a temperature of $+16^{\circ} \mathrm{C}$ $17^{\circ} \mathrm{C}$, the leaves dry out and the aboveground part dies off completely.

\section{Conclusions}

Thus, the intensity of growth and development of capers in the spring largely depends on meteorological conditions. Under favorable conditions, capers begin growing in early April, bloom in early May, bear fruit in June-August and finish growing at the end of October, even November, if there is no frost. The versatile useful properties of capers indicate the possibility of its integrated use, first of all, as an object for the development of empty waterless territories of the republics of Uzbekistan; as a first-class honeybee in beekeeping, as well as oilseed, sugar-bearing, vegetable and fodder in karakul breeding. The natural renewal in the Tashkent region is satisfactory. However, in recent years, the strong impact of anthropogenic factors has led to a reduction in the natural areas of capers. During the budding period, the local population collects the fruits of the plant and marinates them. The fruits are edible, as a result of which we have not found mature fruits, and this has a negative effect on natural renewal.

The renewal of capers in natural conditions is carried out by seed and vegetative means, but rather weakly. Low seed germination is one of the biological features of this plant. In the soil, caper seeds persist for a long time and can germinate in a few years. Therefore, it is necessary to store seeds underground from December to March for the passage of cold stratification. The plants do not require irrigation and do not suffer from summer heat and dryness. Capers belong to the number of plants that are ecologically adapted to xerothermal conditions and can be used for the ecological restoration of inefficient lands-the development of clay degraded places of the foothill and desert zones of the Republic of Uzbekistan. The plant is also important for beekeeping and the creation of a forage base in the desert and semi-desert zones of the republic. Sowing and creating a caper plantation in these zones is of interest for use in both the medicinal and food industries, as well as for the development of beekeeping.

\section{Conflicts of Interest}

The authors declare no conflicts of interest regarding the publication of this paper.

\section{References}

[1] Larin, I.V., Aghababyan, Sh.M., Rabotnov, T.A., Lyubskaya, A.F., Larina, V.K. and Kasimenko, M.A. (1951) Forage Plants of Hayfields and Pastures in the USSR. Vol. 2. Selkhozgiz, Moscow-Leningrad, 402 p. (In Russian)

[2] Khassanov, F.O. (2015) Conspectus Florae Asiae Mediae. Vol. XI. Fan, Tashkent, 63-78. (In Russian)

[3] Flora of Uzbekistan (1955) Tashkent: Academy of Sciences of the UzSSSR. Vol. 3. 58-64. (In Russian)

[4] Zakirov, K.Z. and Khudayberganov, R. (1972) Capparis spinosa and Prospects for 
Its Use. Fan, Tashkent, 119 p. (In Russian)

[5] Toyjonov, K., Nigmatullaev, B.A. and Sagdullaev, Sh.Sh. (2016) Etymological Dictionary of Latin Names of Medicinal Plants of Uzbekistan. Navruz, Tashkent, 38 p. (In Russian)

[6] Khodzhimatov, K.Kh., Aprasidi, G.S. and Khodzhimatov, A.K. (1995) Wild-Growing Medicinal Plants of Central Asia. Abu Ali ibn Sino, Tashkent, 32-33. (In Russian)

[7] Khamidov, G. (1968) The Main Melliferous Plants of Uzbekistan. Fan, Tashkent, 22-23. (In Russian)

[8] Khodzhimatov, O.K. (2021) Medicinal Plants of Uzbekistan (Properties, Application and Rational Use). Manawiyat, Tashkent, 9-10. (In Russian)

[9] Eshankulova, N.T. and Axmedova, Z.R. (2013) Thermoxerophyte-Capparis spinosa L. and Its Distribution in the Desert Areas of Jizzakh Region, as Well as Some Biological Aspects. News of the National University of Uzbekistan. 4/2. Tashkent. 95-98. (In Russian)

[10] Yili, A., Tao, W., Sagdullaev, B.T., Aisa, H.A., Ulchenko, N.T., Glushenkova, A.I. and Rakhmanberdyeva, R.K. (2006) Lipids and Carbohydrates from Capparis spinosa. Chemistry of Natural Compounds, 42, 100-101. https://doi.org/10.1007/s10600-006-0046-1

[11] Ramezani, Z., Aghel, N. and Keyghobadi, H. (2008) Rutin from Different Parts of Capparis spinosa Growing Wild in Khuzestan/Iran. Pakistan Journal Biological Sciences, 11, 768-772. https://doi.org/10.3923/pjbs.2008.768.772

[12] Yang, T., Wang, Ch., Liu, H., Chou, G., Cheng, X. and Wang, Z. (2010) A New Antioxidant Compound from Capparis spinosa. Pharmaceutical Biology, 48, 589-594. https://doi.org/10.3109/13880200903214231

[13] Cao, Y.-L., Li, X. and Zheng, M. (2010) Capparis spinosa Protects against Oxidative Stress in Systemic Sclerosis Dermal Fibroblasts. Archives of Dermatological Research, 302, 349-355. https://doi.org/10.1007/s00403-009-0998-7

[14] Bhoyar, M.S., Mishra, G.P., Pradeep, K.N. and Srivastava, R.B. (2011) Estimation of Antioxidant Activity and Total Phenolics among Natural Populations of Capparis spinosa Leaves Collected from Cold Arid Desert of Trans-Himalayas. Australian Journal of Crop Science, 5, 912-919.

[15] Mohammad, Sh.M., Kashani, H.H. and Azarbad, Z. (2012) Capparis spinosa L. Propagation and Medicinal Uses. Life Science Journal, 9, 684-686.

http://www.lifesciencesite.com

[16] Anwar, F., Muhammad, G., Hussain, M.A., Zengin, G., Alkharfy, Kh.M., Ashraf, M. and Gilani, A.-H. (2016) Capparis spinosa L.: A Plant with High Potential for Development of Functional Foods and Nutraceuticals/Pharmaceuticals. International Journal of Pharmacology, 12, 201-219. https://doi.org/10.3923/ijp.2016.201.219

[17] Nabavi, S.F., Maggi, F., Daglia, M., Habtemariam, S., Rastrelli, L. and Nabavi, S.M. (2016) Pharmacological Effects of Capparis spinosa L. Phytotherapy Research, 30, 1733-1744. https://doi.org/10.1002/ptr.5684

[18] Mollica, A., Zengin, G., Locatelli, M., Stefanucci, A., Mocan, A., Macedonio, G., Carradori, S., Onaolapo, O., Onaolapo, A., Adegoke, J., Olaniyan, M., Aktumsek, A. and Novellino, E. (2017) Anti-Diabetic and Anti-Hyperlipidemic Properties of Capparis spinosa L.: In Vivo and in Vitro Evaluation of Its Nutraceutical Potential. Journal of Functional Foods, 35, 32-42. https://doi.org/10.1016/j.jff.2017.05.001

[19] Benzidane, N., Aichour, R., Guettaf, S., Laadel, N., Khennouf, S., Baghiani, A. and Arrar, L. (2020) Chemical Investigation, the Antibacterial and Antifungal Activity 
of Different Parts of Capparis spinosa Extracts. Journal of Drug Delivery and Therapeutics, 10, 118-125. https://doi.org/10.22270/jddt.v10i5.4388

[20] The Climate of Tashkent (1982) Leningrad: Gidrometeoizdat. 199 p.

[21] Rabotnov, T.A. (1960) Methods for Studying Seed Reproduction of Herbaceous Plants in communities. In: Field Geobotany, Vol. 2, USSR Academy of Sciences, Moscow-Leningrad, 20-39. (In Russian)

[22] (1980) Methodical Instructions for Seed Science of Introduced Species. Science, Moscow, 64. (In Russian)

[23] Nikolaeva, M.G., Razumova, M.V. and Gladkova, V.N. (1985) Dormant Seed Germination Guide. Science, Leningrad, 177-178. (In Russian)

[24] Rabbimov, A., Ergashev, Sh.M., Rabbimov, E.A., Vaisova, G. and Soliev, X.E. (2020) The Role of Pumpkin in Increasing the Efficiency of Use of the Hills of Samarkand Region. Innovative Development of Samarkand Region: Problems and Solutions. Materials of the Republican Scientific-Practical Conference, Samarkand, 26-27 November 2020, 344-346.

[25] Rabotnov, T.A. (1950) Issues of Studying the Composition of Populations for the Purposes of Phytocenology. Problems of Botany, 1, 465-483. (In Russian)

[26] Serebryakov, I.G. (1952) Morphology of Vegetative Organs of Higher Plants. Soviet Science, Moscow, 74-92. (In Russian)

[27] Borisova, I.V. (1972) Seasonal Dynamics of the Plant Community. In: Field Botany, Vol. 4, Science, Leningrad, 5-94. (In Russian)

[28] Beideman, I.N. (1974) Methodology for Studying the Phenology of Plants and Plant Communities. Science, Novosibirsk, 4-108. (In Russian) 